\title{
Type 2 (non-insulin-dependent) diabetes mellitus and HLA antigens in Papua New Guinea
}

\author{
K. Bhatia ${ }^{1}$, M. Patel ${ }^{2}$ and M. Gorogo ${ }^{1}$ \\ ${ }_{1}^{1}$ Papua New Guinea Institute of Medical Research, Goroka, and ${ }^{2}$ Department of Clinical Sciences, Medical Faculty, \\ University of Papua New Guinea, Boroko, Papua New Guinea
}

\begin{abstract}
Summary. HLA phenotypes were studied in 57 Type 2 (noninsulin-dependent) diabetic Papuan patients and the results compared with control subjects of the same Austronesian origin. An association was found between disease and BW62, a split antigen of B15, with corrected probability significant at the $5 \%$ level. The frequencies of B13 and BW 22 were also increased in diabetic patients but the differences were not statistically significant. Although it has been postulated that $\mathrm{Me}-$
\end{abstract}

lanesian communities have protection against diabetes, they have a high frequency of BW62, which would imply, from the association found in this study, that susceptibility to Type 2 diabetes has yet to become manifest in them.

Key words: Type 2 diabetes, HLA antigens, Papua New Guinea, diabetes genetics.
Type 2 (non-insulin-dependent) diabetes mellitus is emerging as a concern to public health in the urban centres of Papua New Guinea [1-3]. This increase in prevalence is attributed largely to the rapid socio-economic changes and the adoption of a Westernised life-style which unmasks the underlying genetic predisposition to the disease as is seen in the other Pacific nations [1, 4].

Family and twin studies have established that Type 2 diabetes has a stronger genetic component than Type 1 (insulin-dependent) diabetes [5], but the precise definition of the major genes responsible for the former has been more difficult to establish. This problem is accentuated by the failure to detect an association between Type 2 diabetes and histocompatibility antigens (HLA) in most population groups [6,7]. However, HLA studies on selected ethnic groups have shown a small but consistent risk for developing Type 2 diabetes associated with antigens of HLA-A and -B loci [8-13]. These observations indicate that a careful analysis of such an association in different ethnic groups may provide clues relating to the genetics of this form of diabetes [12].

We have studied the association of Type 2 diabetes with antigens of HLA-A and -B loci in diabetic patients from the Papuan (southern) coast of Papua New Guinea.

\section{Subjects and methods}

\section{Subjects}

Fifty-seven patients were selected for the study from patients attending the diabetic clinic at Port Moresby General Hospital. Most of the patients originated from the Marshall Lagoon and Rigo areas of Cen- tral Province. The other large group included in the study was from Hanuabada and Pari villages within the Port Moresby area, also in Central Province. Three subjects each were from Kerema in Gulf Province and Samarai in Milne Bay Province. All of the patients were therefore from the Papuan region and spoke Motu or another closelyrelated Austronesian language.

The diagnosis of diabetes was based on the criteria recommended by the WHO Expert Committee on Diabetes [14]. At the time of presentation, all the patients had diabetes with symptoms or signs related to the complications of the disease. None was ketosis-prone and most were obese ( 33 out of 57 ). The mean age at onset of diabetes was

Table 1. HLA-A and -B locus antigens and their gene frequencies in Type 2 diabetic patients from Papua New Guinea

\begin{tabular}{|c|c|c|c|c|c|c|c|}
\hline \multirow[t]{2}{*}{ Locus } & \multirow[t]{2}{*}{ Antigen } & \multirow{2}{*}{\multicolumn{2}{|c|}{$\begin{array}{l}\text { Number } \\
\text { positive }\end{array}$}} & \multirow{2}{*}{\multicolumn{2}{|c|}{$\begin{array}{l}\text { Antigen } \\
\text { frequency }\end{array}$}} & \multicolumn{2}{|c|}{ Gene frequency } \\
\hline & & & & & & $\begin{array}{l}\text { Square- } \\
\text { root } \\
\text { method }\end{array}$ & $\begin{array}{l}\text { Gene } \\
\text { counting } \\
\text { method }\end{array}$ \\
\hline \multirow{7}{*}{$\begin{array}{l}\text { HLA-A } \\
(n=57)\end{array}$} & A2 & 6 & \multirow{6}{*}{21} & 0.105 & \multirow{6}{*}{0.369} & 0.054 & 0.053 \\
\hline & AW24 (A9) & 47 & & 0.825 & & 0.581 & 0.570 \\
\hline & A26 (A10) & 7 & & 0.123 & & 0.063 & 0.061 \\
\hline & AW34 (A10) & 14 & & 0.246 & & 0.131 & 0.158 \\
\hline & A11 & 11 & & 0.193 & & 0.102 & 0.114 \\
\hline & A28 & 5 & & 0.088 & & 0.045 & 0.044 \\
\hline & $\Sigma$ & & & 1.558 & & 0.977 & 1.000 \\
\hline \multirow{9}{*}{$\begin{array}{l}\text { HLA-B } \\
(n=57)\end{array}$} & B13 & 24 & \multirow{5}{*}{28} & 0.421 & \multirow{6}{*}{0.492} & 0.239 & 0.219 \\
\hline & BW62 (B15) & 17 & & 0.298 & & 0.162 & 0.175 \\
\hline & BW39 (B16) & 9 & & 0.158 & & 0.082 & 0.079 \\
\hline & BW54 (B22) & 1 & & 0.018 & & 0.009 & 0.009 \\
\hline & BW56 (B22) & 27 & & 0.474 & & 0.275 & 0.272 \\
\hline & B27 & 2 & \multirow{3}{*}{25} & 0.035 & & 0.018 & 0.018 \\
\hline & $\mathrm{BW} 60(\mathrm{~B} 40)$ & 23 & & 0.407 & \multirow{2}{*}{0.439} & 0.228 & 0.210 \\
\hline & BW61 (B40) & 2 & & 0.035 & & 0.018 & 0.018 \\
\hline & $\Sigma$ & & & 1.843 & & 1.030 & 1.000 \\
\hline
\end{tabular}


Table 2. Relative risks of Type 2 diabetes for B13, B15 (BW62), and BW22 antigens in Port Moresby area

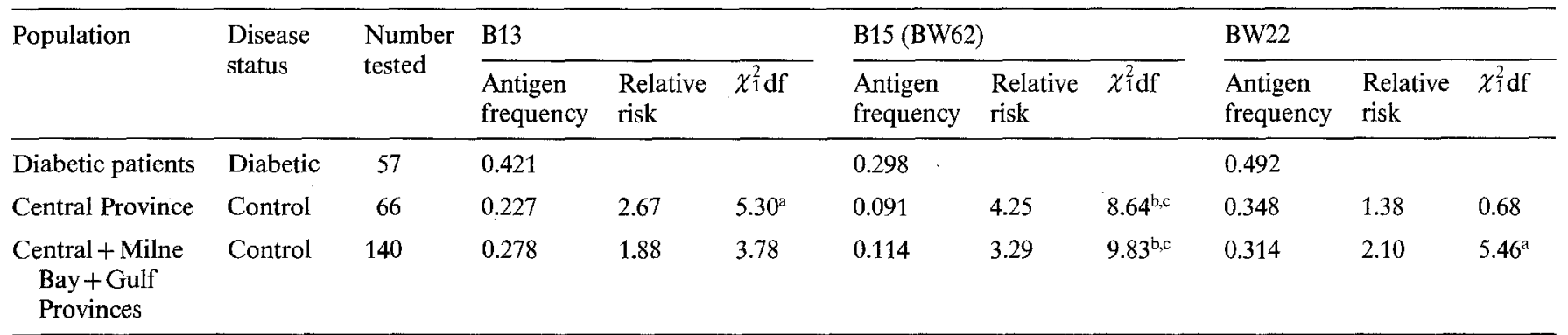

$\chi_{1}^{2} \mathrm{df}=$ chi-square significance of the difference. ${ }^{\mathrm{a}} 0.01<p<0.05 ;{ }^{\mathrm{b}} p<0.01 ;{ }^{\mathrm{c}}$ corrected $0.01<p<0.05$

40 years (range 23-61 years). Mean duration of disease was 4.3 years and varied between 6 months to 20 years. Twenty-two patients had microvascular complications (retinopathy or significant proteinuria), one had suffered a myocardial infarct, another had had a foot amputated due to atheroma, while one patient had a hemiplegia due to cerebral infarction. Twenty-seven patients had been admitted to hospital on one or more occasions for severe infections.

\section{Methods}

Heparinised blood $(30 \mathrm{ml})$ was collected from each patient in Port Moresby and air-freighted at room temperature on the same day to Goroka. Mononuclear cells were separated within $24 \mathrm{~h}$ of blood collection by flotation on Ficoll-Isopaque. The procedures used for the separation of T lymphocytes and the typing of HLA-A and -B locus antigens are given by Bhatia et al. [15].

\section{Statistical analysis}

Frequencies of HLA antisera in patients were compared with those in two control populations from the same geographical area reported by Ting et al. [16]. The significance of association of individual HLA antigens with Type 2 diabetes was tested by $2 \times 2 \chi^{2}$ contingency comparisons. The significance level of probability of each chi-square value was corrected for the number of antigens recovered in the sample at the locus in question. The relative risk of developing the disease for a particular antigen was obtained by the odds ratio. Gene frequencies were calculated by using both the square root and the gene counting methods.

\section{Results}

The antigen and gene frequencies for HLA-A and -B loci in all diabetic patients are shown in Table 1. The two major groups of patients included in the study, one from the Marshall Lagoon and Rigo areas and the other from the Hanuabada and Pari villages in Port Moresby area, showed no significant differences from each other for antigen frequencies at either HLA-A or -B loci; consequently, the data were pooled for comparison with the controls. The estimates of gene frequencies obtained from the two methods showed no differences from each other, thus indicating the relative lack of unidentified antigens in this study.

Comparison of the frequencies of HLA antigens between diabetic and control groups revealed similar distributions with no significant differences at the HLA-A locus. However, a number of antigens at the HLA-B lo- cus (B13, BW22 and B15) showed increased frequencies in diabetic patients (Table 2) with no concomitant significant decreases in frequencies of other HLA antigens. Of these, B13 and BW22 showed an increase which was not significant. Only BW62 (a split antigen of B15) showed differences from the two controls which were significant at the $5 \%$ level of corrected probability.

\section{Discussion}

This report of an increased association of BW62 with Type 2 diabetes in coastal Papuans supports the suggestion by Serjeantson et al. of minor MHC influences in Type 2 diabetes in non-European populations [12]. This has been shown to occur for HLA-A2 among Pima Indians [10] and among the Xhosa of South Africa [9], and for HLA-BW61 among Asian Indians who have migrated to Fiji [12].

The HLA studies of Serjeantson et al. in diabetic patients from other Pacific islands are relevant to our findings. Nauruans who develop diabetes before the age of 46 years have a significantly decreased frequency of BW62 [8], but this antigen is not clearly implicated in diabetic patients from four other Pacific islands although the frequency of B15 (BW62) is increased in diabetics in Melanesian populations [13, present study]. Recently, Serjeantson et al. [17] have reported two variants of BW62 in Melanesians from New Caledonia, and it is likely that such heterogeneity may have affected the significance of earlier results.

In Micronesians [8] and Polynesians [13], Serjeantson and her co-workers have found significantly increased risks for the development of Type 2 diabetes in the presence of BW22. Similar, though non-significant, increases were found in Melanesians from Fiji, New Caledonia and Loyalty Islands [13]. In the light of Serjeantson's findings, the increase in the frequency of BW22 in Papuans reported in this study indicates that this antigen is associated with a real but small increase in risk for Type 2 diabetes in the Pacific.

In our sample of diabetic patients, the frequency of unidentified alleles was found to be low. In contrast, the frequency of blank alleles in the control population, investigated by Ting et al. [16], was about $20 \%$. We have 
compared the antigen frequencies of HLA-A and -B loci studied by our group with those reported by other investigators for a number of New Guinean populations $[15$, K. Bhatia and M. Gorogo, unpublished observations]. No significant differences in antigen frequencies, specially in those of B13, BW22 and B15 (BW62), were noticed. It is, therefore, unlikely that the differences in antigen frequencies of B15 (BW62) and BW22 between the diabetic patients and control groups can be explained by the incomplete definition of Melanesian antigens in 1970's.

Melanesian populations reported to have a high prevalence of Type 2 diabetes in Fiji [18], New Caledonia [18], Torres Strait Islands [19], New Britain [2] and in urban Papua [1], are all of Austronesian origin. Diabetes does not occur at present in non-Austronesian populations of highland Papua New Guinea [20]. However, one disturbing fact is that the antigen frequency of BW62 in highlanders is more than 40\% [15]. Most of the highland populations have been exposed to a modern life-style for a relatively short period and if the Type 2 diabetes-HLA associations have any prognostic implications, the increasing modernisation of these traditional societies is cause for concern. Longitudinal studies are in progress at the Papua New Guinea Institute of Medical Research to monitor glucose intolerance in these highland communities.

Acknowledgements. We are most grateful to Dr. H. Bashir for advice and support with this project and specially acknowledge Mr. T. Doran for help with HLA antisera. Comments of Drs. M. Alpers and S.Serjeantson on an earlier draft of this paper have helped improve the presentation, for which we are thankful.

\section{References}

1. Martin FIR, Wyatt GB, Griew AR, Harurahelia M, Higginbotham L (1980) Diabetes mellitus in urban and rural communities in Papua New Guinea. Diabetologia 18: 369-374

2. Savige $\mathbf{J}(1982)$ Diabetes mellitus in the Tolais of Gazelle peninsula, New Britain. Papua New Guinea Med J 25: 89-92

3. Martin FIR (1978) The clinical characteristics of diabetes mellitus in Papua New Guinea. Papua New Guinea Med J 21: 317-322

4. Zimmet P, Whitehouse S (1981) Pacific islands of Nauru, Tuvalu and Western Samoa. In: Trowell HC, Burkitt DP (eds) Western diseases: their emergence and prevention, Edward Arnold, London, pp 204-226

5. Notkins AL (1979) The cause of diabetes. Sci Am 241: 56-57

6. Nerup J, Platz P, Ortved Anderson O, Christy M, Lyngsøe J, Poulsen JE, Ryder LP, Staub Nielsen L, Thomsen M, Svejgaard A (1974) HL-A antigens and diabetes mellitus. Lancet 2: 864-866
7. Rotter JI (1981) The modes of inheritance of insulin-dependent diabetes mellitus or the genetics of IDDM, no longer a nightmare but still a headache. Am J Hum Genet 33: 835-851

8. Serjeantson SW, Owerbach D, Zimmet P, Nerup J, Thoma K (1983) Genetics of diabetes in Nauru - effects of foreign admixture, HLA antigens and the insulin-gene-linked polymorphism. Diabetologia 25:13-17

9. Briggs BR, Jackson WPU, Du Toit ED, Botha MC (1980) The histocompatibility (HLA) antigen distribution in South African blacks (Xhosa). Diabetes 29: 68-70

10. Williams RC, Knowler WC, Butler WJ, Pettitt DJ, Lisse JR, Bennet PH, Mann DL, Johnson AH, Terasaki PI (1981) HLA-A2 and Type 2 (insulin-independent) diabetes mellitus in Pima Indians: an association of allele frequency with age. Diabetologia 21: $460-463$

11. Asmal AC, Dyal B, Jialal I, Leary WP, Omar MAK, Pillay NL, Thandroyen FT (1981) Non-insulin-dependent diabetes mellitus with early onset in Blacks and Indians. S Afr Med J 60:93-96

12. Serjeantson SW, Ryan DP, Ram P, Zimmet P (1981) HLA and non-insulin-dependent diabetes in Fiji Indians. Med J Aust 1: $462-463$

13. Serjeantson SW, Ryan DP, Zimmet P, Taylor R, Cross R, Charpin M, Gonidec G (1982) HLA antigens in four Pacific populations with non-insulin-dependent diabetes mellitus. Ann Hum Biol 9: 69-84

14. World Health Organization (1980) WHO Expert Committee on Diabetes. Second report. Technical Report Series 646, Geneva

15. Bhatia K, Gorogo M, Koki G (1984) HLA-A, B, C and DR antigens in Asaro speakers of Papua New Guinea. Hum Immunol 9: $189-200$

16. Ting A, James M, Woodfield DG, Morris PJ (1972) The distribution of HLA antigens in the coastal populations of Papua New Guinea. Tissue Antigens 2: 409-417

17. Serjeantson SW, Helias M, Gonidec G Le, Newlands R (1983) Ethnic report - Melanesians from New Caledonia. In: Simons MJ, Tait BD (eds) Proceedings of the Second Asia and Oceania Histocompatibility Workshop Conference. Immunopublishing, Melbourne, pp 299-309

18. Zimmet P, King H (1982) Epidemiological studies of diabetes mellitus in Pacific populations: a review. In: Tuomilehto J, Zimmet P, King M, Pressley M (eds) Diabetes mellitus: primary health care, prevention and control. International Diabetes Federation, Australia, pp 8-21

19. Duffy P, Morris H, Nielson G (1981) Diabetes mellitus in the Torres Straits region. Med J Aust (Special Supplement on Aboriginal Health) 13: 8-11

20. King H, Heywood P, Zimmet P, Alpers M, Collins V, Collins A, King LF, Raper RL (1984) Glucose tolerance in a highland population in Papua New Guinea. Diabetes Research 1: 45-51

Received: 8 December 1983

and in revised form: 14 May 1984

Dr. K. Bhatia

PNG Institute of Medical Research

P.O. Box 60

Goroka

Papua New Guinea 